PRZEGLĄDY - POLEMIKI - MATERIAEY

Kwartalnik Historyczny Rocznik CXXIV, 2017, 1 PL ISSN 0023-5903

MAREK SEOŃ

Instytut Historii PAN, Warszawa

\title{
W ODPOWIEDZI NA UWAGI TOMASZA JURKA ZAWARTE W RECENZJI KSIĄŻKI JANUSZA TANDECKIEGO, KRZYSZTOFA KOPIŃSKIEGO EDYTORSTWO ŹRÓDE€ HISTORYCZNYCH
}

Tomasz Jurek w swej recenzji ${ }^{1}$ poświęcił obszerny ustęp polemice z moimi propozycjami, które "dotykają samej istoty rozumienia roli edytorstwa” (dalej cyt.: TJ, s. 361). Pretekstem stał się akapit zamieszczony w moim omówieniu tejże książki („Studia Źródłoznawcze” 52, 2014, s. 183-186, dalej cyt.: MS, s. 184). Stwierdzam tam, że obecnie przepisanie i przedruk tekstu nie są już konieczne dla rozpowszechnienia zawartości źródła, ponieważ można to łatwiej osiągnąć udostępniając jego skan, co każe przemyśleć na nowo pryncypia naukowego edytorstwa. W istocie głos polemiczny odnosi się jednak nie do tych uwag, lecz do koncepcji zaprezentowanej kilkakrotnie na konferencjach i w formie publikacji. Najważniejszy jest tu artykuł, który ukazał się w kolejnym tomie „Studiów Źródłoznawczych" (Pryncypia edytorstwa źródeł historycznych w dobie rewolucji cyfrowej, 53, 2015, s. 155-161, dalej cyt.: Pryncypia). Tomasz Jurek nie przywołuje jednak ani tego, ani innych tekstów, a przedstawiając moje propozycje, zniekształca je w zasadniczych punktach.

Zdaniem poznańskiego historyka za wystarczającą formę edycji uznaję skan źródła: „Starczy więc udostępnić reprodukcję rękopisu, a każdy historyk przeczyta go sobie sam" (TJ, s. 361). Stwierdzam coś zupełnie innego: „Udostępnienie obrazu oryginału powinno być obecnie kardynalną zasadą każdej edycji" (MS, s. 184), czyli postulowanym dodatkiem. Zarazem podkreślam, że „na pewno nie jest edycją źródłową ani

1 T. Jurek, rec.: Janusz Tandecki, Krzysztof Kopiński, Edytorstwo źródeł historycznych, Warszawa 2014, KH 123, 2016, 2, s. 357-362. 
sama digitalizacja rękopisu, ani jej udostępnienie w sieci lub na jakimś nośniku" (Pryncypia, s. 157). Tomasz Jurek przypisuje mi nadzieję, że opatrywanie cyfrowego faksymile komentarzem i indeksami „może zastąpić i wyprzeć tradycyjne edycje” (TJ, s. 361). Twierdzę, że „edycje zgodne z wypracowanymi przez pokolenia zasadami oczywiście nadal mają sens - ale nie tylko one" (Pryncypia, s. 160). W przywołanej recenzji czytamy także, że „M. Słoń kwestionuje mianowicie samą potrzebę kopiowania tekstu na potrzeby edycji” (TJ, s. 361). Rzeczywiście twierdzę, że „aby udostępnić odbiorcy treść zabytku odpis nie jest już wcale niezbędny”, dodając jednak od razu, że „Stanowi jedno z narzędzi pomagających w lekturze. Niejednokrotnie jest to instrument ważny, czasem wręcz podstawowy" (MS, s. 184). Po prostu rola edycji wykracza poza samo udostępnienie treści źródła. Proponowana koncepcja edytorstwa to ponoć „pomysł publikowania w Internecie skanów rękopisów z odpowiednim komentarzem krytycznym oraz bazą danych indeksujących informacje o ludziach i miejscowościach" (TJ, s. 361). Baza danych oczywiście nic nie indeksuje, robią to historycy, posługując się tym narzędziem do sporządzenia i udostępnienia odpowiednich zestawień. Opracowywana jako przykładowa edycja najstarszej wschowskiej księgi grodzkiej (zob. www. atlas.fontium.pl - prace w toku) zawierała również elementy indeksu rzeczowego, datację wszystkich zapisek, identyfikację rąk pisarskich i pełen odczyt wybranych not.

Mimo tych przeinaczeń cieszy mnie podjęcie dyskusji nad zasadami edytorstwa, bo taki był właśnie cel sformułowania propozycji w tym względzie. Korzystając z tej okazji, odniosę się do dwóch kwestii podniesionych przez mojego znakomitego adwersarza.

Tomasz Jurek stwierdza, że ,istnieje podstawowa różnica między odczytem, który można uznać zasadniczo za obiektywny, a tłumaczeniem, które zawsze jest formą mniej lub dalej idącej interpretacji tekstu" (TJ, s. 361). Dwa zdania dalej pisze jednak, że „doświadczenie edytorstwa pokazuje, jak wielką i żmudną pracą jest właściwe ustalanie tekstu, wychodzące przeważnie poza samo złamanie kodu graficznego". Z tą drugą opinią w pełni się zgadzam. Co więcej, dopóki rękopis nie sprawia żadnych trudności interpretacyjnych, jego odczyt jest raczej czynnością mechaniczną, którą wcześniej czy później zastąpią programy OCR, a nie sztuką edytorską. Poznański historyk sam znakomicie pokazał więc zasadność porównania tłumaczenia i „ustalania tekstu”. Różnica między nimi jest ilościowa - przekład zawiera zazwyczaj większą dawkę interpretacji - a nie jakościowa. Obie formy ułatwiają odbiorcy edycji percepcję tekstu, zarazem oddalając go od oryginału. Taka jest ogólnie rzecz biorąc najważniejsza funkcja edytorstwa źródeł historycznych, co ładnie 
ujął Tomasz Jurek: „zawsze podstawowym elementem pracy wydawcy musi pozostać uprzystępnienie tekstu źródłowego" (TJ, s. 361, podkreślenie - MS). W poprzednim zdaniu podkreśla wage „propozycji M. Słonia, która rzeczywiście może pozwolić na uprzystępnienie wielu masowych źródeł" (podkreślenie - MS). Pozwala to żywić nadzieję, że dalsza dyskusja przyniesie wspólne konkluzje i mniej nieporozumień.

Biogram: dr hab. Marek Słoń, prof. IH PAN, kierownik Zakładu Atlasu Historycznego IH PAN, zainteresowania: historia miast i religijności w średniowieczu; geografia historyczna; edytorstwo źródeł; kontakt: marek.slon@wp.pl. 